\title{
STRATEGI PENGELOLAAN HUTAN RAKYAT DI KABUPATEN SINJAI
}

\author{
(People's Forest Management Strategy in Sinjai District)
}

\author{
Lenny Marlina Zainal*, A. Tjoneng**, S. Numba**
}

*Mahasiswa Program Studi Magister Agroekoteknologi

**Dosen Program Studi Agroekoteknologi Fakultas Pertanian Universitas Muslim Indonesia, Makassar.

\begin{abstract}
The Strategy of Social Forest Management in Sinjai Regency was examined using SWOT and AHP methods. This method is carried out by collecting information on internal factors (strengths and weaknesses) and external (opportunities and threats) of respondents consisting of Forest Comunity, Head of Forestry Division of Environment and Forestry OfficeSinjai Regency, the village head involved in the community forest program, \& the Forestry Counselor of Sinjai Regency. Based on this information in the development of Social Forestry a strategy should be determined as an alternative strategy that must be applied. To determine the best alternative that will be applied in accordance with the purpose then used the incorporation of SWOT and AHP methods to compare the existing alternatives. The Social Forest Management Strategy of Sinjai Regency based on its priorities consists of: (1) Strengthening the role of the group by providing accurate market information (2) Conducting forestry and guidance from the government for the management of the area and the formulation of the management plan. (3) The Government facilitates the licensing to establish a timber industry to increase the value of timber and (4) using agroforestry System.
\end{abstract}

Keywords : Social Forest, SWOT \& AHP

\section{PENDAHULUAN}

Pengelolaan hutan rakyat sangat layak untuk dioptimalkan jika mengingat adanya tantangan berat bagi rehabilitasi hutan yang semakin hancur dewasa ini. Dengan mengelola hutan rakyat, tekanan yang hebat terhadap hutan negara lambat laun akan dapat dihilangkan atau setidaknya dapat ditekan. Berdasarkan UU Kehutanan No. 41 tahun 1999 pengembangan hutan rakyat diarahkan kepada usaha-usaha rehabilitasi dan konservasi lahan di luar kawasan hutan negara, penganekaragaman hasil pertanian yang diperlukan oleh masyarakat, peningkatan pendapatan masyarakat, penyediaan kayu sebagai bahan baku bangunan, bahan baku industri, penyediaan kayu bakar, usaha perbaikan tata air dan lingkungan, serta sebagai kawasan penyangga bagi kawasan hutan negara.

Di Kabupaten Sinjai telah dikembangkan hutan rakyat seluas 6.245 ha dengan jumlah tegakan 2.268.162 pohon yang tersebar di delapan Kecamatan dapat dilihat pada Tabel 1. Dibawah ini. 
Tabel 1. Luas Hutan Rakyat di Kabupaten Sinjai Propinsi SulawesiSelatan.

\begin{tabular}{rlr}
\hline \hline No & \multicolumn{1}{c}{ Kecamatan } & Luas (ha) \\
\hline \hline 1. & Sinjai Tengah & 345,0 \\
2. & Sinjai Timur & 374,0 \\
3. & Sinjai Selatan & 260,5 \\
4. & Tellulimpoe & 705,0 \\
5. & Bulupoddo & 694,0 \\
6. & Sinjai Borong & 390,5 \\
7. & Sinjai Barat & 3002,0 \\
8. & Sinjai Utara & 377,0 \\
\hline \hline
\end{tabular}

Sumber: Disbunhut Kab. Sinjai, 2015.

Masalah yang dikaji pada penelitian

ini adalah (1) merumuskan dan mengevaluasi peran Pemerintah dalam implementasi kebijakan pengelolaan hutan rakyat, (2) mengidentifikasi faktor-faktor penunjang dan penghambat dalam pelaksanaan kegiatan tersebut dan (3) merumuskan strategi pembangunan hutan rakyat melalui keterlibatan bersama pemangku kepentingan. Penelitian ini untuk menganalisis strategi pengelolaan Hutan Rakyat dan menentukan strategi prioritas pengelolaan Hutan Rakyat di kabupaten Sinjai.

\section{METODE PENELITIAN}

\section{Waktu dan Lokasi Penelitian}

Penelitian ini dilaksanakan dari Februari sampai dengan Mei 2017. Penelitian dilaksanakan di Kecamatan Tellulimpoe dan Sinjai Barat Kabupaten Sinjai.

\section{Teknik Pengumpulan Data dan Jenis} Data

Responden dari penelitian ini adalah petani yang mengelolah hutan rakyat dan wakil dari Pemerintah yang mengetahui program hutan rakyat. Pengambilan sampel dilakukan secara sengaja (purposive sampling) dengan pertimbangan bahwa responden mengetahui program hutan Rakyat. Responden terdiri dari (1) Petani Hutan Rakyat, (2) Kepala Bidang Kehutanan Dinas Lingkungan Hidup dan Kehutanan Kab. Sinjai, (3) Kepala Desa yang terlibat dalam program hutan rakyat, (4) Penyuluh Kehutanan Kab. Sinjai

\section{Metode Pengambilan Data}

Pengambilan data dalam penelitian ini dilakukan dengan metode survei yang dilakukan dengan kuisioner dan wawancara mendalam terhadap responden untuk memperoleh data yang dibutuhkan untuk analisi SWOT dan data sub elemen dalam 
tiap elemen untuk penyusunan struktural pengembangan hutan rakyat. Pemilihan atau penetapan lokasi penelitian untuk responden petani dilakukan pada tingkat kecamatan dengan mempertimbangkan luas areal hutan rakyat yang dimiliki masing-masing kecamatan.

Penentuan sampel dilakukan dengan cara acak (simple random sampling) dengan menentukan 27 orang responden petani pengelolah hutan rakyat dan 17 orang responden dari aparat pemerintah yang terlibat dalam pengelolaan hutan rakyat.

\section{Analisis Data}

Sesuai dengan tujuan penelitian, analisis yang digunakan dalam penelitian ini adalah analisis Statistik Deskripif, analisis SWOT (Strength, weakness, opportunity, threat) \&analisis AHP (analytical hierarchy process).

Tujuan pertama yakni merumuskan dan mengevaluasi peran Pemerintah dalam pengelolaan hutan rakyat dan identifikasi peubah strategis unsur internal dan eksternal serta pengaruhnya terhadap perkembangan hutan rakyat yang mendukung pengelolaan sumberdaya hutan secara berkelanjutan di
Kabupaten Sinjai dijelaskan melalui analisis SWOT (strength, weakness, opportunity, dan threat). Analisis ini pada dasarnya dilakukan melalui penelusuran dan pengungkapan isu-isu strategis disekitar pembangunan hutan rakyat untuk selanjutnya dipakai sebagai dasar dalam penyusunan strategi. Penentuan tingkatan prioritas dalam SWOT ini dilakukan dengan menggunanakan AHP melalui wawancara pakar dan pengolahan datanya dilakukan dengan bantuan program Expert Choice 11.

\section{HASIL DAN PEMBAHASAN}

\section{Peran Stakeholder}

Seiring dengan otonomi daerah, pelimpahan sebagian wewenang pemerintah pusat kepada pemerintah daerah berlaku juga untuk bidang kehutanan di Kabupaten Sinjai. Selain terdapat program-program pemerintah pusat, terdapat juga program kehutanan yang dikoordinatori dan merupakan inisiatif pemerintah provinsi maupun kabupaten/kota. Untuk dapat melihat sejauh mana implementasi kebijakan di bidang kehutanan di Kabupaten Sinjai, dapat dilihat pada Tabel 2. 
Tabel 2. Implementasi Kebijakan Publik di bidang Kehutanan di Kabupaten Sinjai.

\begin{tabular}{|c|c|}
\hline Hal & Uraian \\
\hline $\begin{array}{l}\text { Permasalahan } \\
\text { Dasar }\end{array}$ & $\begin{array}{l}\text { 1. Kawasan hutan belum mantap dan jelas batas dan penataannya. } \\
\text { 2. Terjadi konversi lahan hutan sebagai pemukiman, perkebunan, } \\
\text { dan pertanian. } \\
\text { 3. Lahan kritis, penggundulan dan perambahan hutan marak } \\
\text { terjadi. } \\
\text { 4. Semakin sering terjadi bencana banjir, tanah longsor, dan } \\
\text { kekeringan. } \\
\text { 5. Usaha kehutanan belum membuahkan hasil maksimal yang } \\
\text { mengancam kelestarian hasil. } \\
\text { 6. Investasi bidang kehutanan masih minim. } \\
\text { 7. Terjadi distorsi pasar hasil hutan rakyat }\end{array}$ \\
\hline Peran & $\begin{array}{l}\text { 1. Kementerian Kehutanan } \\
\text { 2. Dinas Kehutanan Provinsi dan Dinas Kehutanan yang } \\
\text { menangani kehutanan di kabupaten/kota } \\
\text { 3. Instansi pemerintah dan swasta terkait lainnya } \\
\text { 4. Masyarakat disekitar hutan } \\
\text { 5. Masyarakat umum }\end{array}$ \\
\hline Kebijakan & $\begin{array}{ll}\text { 1. } & \text { Kebijakan pemerintah pusat } \\
\text { 2. Kebijakan pemerintah daerah } \\
\text { 3. Kebijakan perusahaan } \\
\text { 4. Aksi masyarakat } \\
\end{array}$ \\
\hline Instrumen & Pengetahuan, Pasar, Regulasi, Promosi \\
\hline Ekstensi & Promosi pengelolaan hutan lestari, sosialisasi program \\
\hline Verfikasi & $\begin{array}{l}\text { Audit program kehutanan, Sertifikasi hutan lestari baik di hutan } \\
\text { produksi dan hutan rakyat }\end{array}$ \\
\hline
\end{tabular}

Sumber : Hasil Analisis Data, 2017.

Tabel 2 memperlihatkan bahwa ternyata permasalahan kehutanan yang menjadi perhatian masyarakat telah meluas sampai kepada permasalahan ekonomi dan persoalan lingkungan. Kondisi alam Kabupaten Sinjai yang sebagian besar peka dan labil membuat keberadaan hutan sangat diperlukan dan mulai menjadi pemikiran serius. Masyarakat secara umum merasakan imbas dari keberadaan hutan yang terus menyusut, sementara masyarakat yang menggantungkan kehidupannya pada hutan mempunyai masalah dengan usaha kehutanan yang belum dapat memberikan hasil dengan memuaskan. Banyaknya stakeholder yang berperan dalam merumuskan, melaksanakan, dan memantau kehutanan di Kabupaten Sinjai menunjukkan sinergi dan pembagian peran 
dalam penerapan kebijakan di bidang kehutanan yang baik di Kabupaten Sinjai.

Dukungan strategis kebijakan dan program untuk menata hutan di Kabupaten Sinjai, termasuk hutan rakyat merupakan usaha untuk melindungi alam Kabupaten Sinjai dengan tidak meninggalkan kesejahteraan masyarakat. Kebijakan dalam pembangunan hutan rakyat, misalnya, dimaksudkan untuk membangun hutan rakyat lestari yang produktif sekaligus berfungsi konservasi. Dengan adanya kebijakan dan program kehutanan yang baik, diharapkan minat masyarakat untuk mengusahakan hutan rakyat semakin tinggi dan merasa difasilitasi oleh pemerintah.

Adapun peraturan /kebijakan yang diterapkan dalam pengelolaan hutan rakyat di kabupaten Sinjai adalah sebagai berikut :

1) Peraturan Menteri Kehutanan (Permenhut) Nomor P.39/MenhutII/2013 tentang Pemberdayaan Masyarkat Setempat melalui kemitraan kehutanan.

2) Peraturan Menteri kehutanan dan Lingkungan Hidup P.85/Men LHK/SETJEN/KUM.I/II/2016 tentang pengangkutan hasil hutan kayu yang berasal dari hutan Hak.
3) Peraturan Direktur Jenderal Perhutanan sosial dan kemitraan lingkungan hidup Nomor : P.17./PSKL/SET/PSL/02/2010 tentang Pedoman Pelaksanaan Kegiatan Hutan Rakyat.

4) Peraturan Menteri Kehutanan dan Lingkungan Nomor P.32 /Men LHKSETJEN/2015 Tentang Hutan Hak.

5) Peraturan Daerah Kabupaten Sinjai Nomor 05. Tahun 2012 Tentang Retribusi Izin Pemanfaatan Kayu Pada Hutan Rakyat / Hutan Milik.

Pemerintah sebagai pembuat Kebijakan untuk tata kelola kehutanan mempunyai peranan yang besar sebagai suatu arahan/pedoman untuk aparat maupun masyarakat dalam pengusahaan hutan rakyat yang produktif dan lestari.

Tanpa tata kelola yang baik, pembangunan hutan rakyat dapat melenceng dari tujuan semula yaitu untuk mengurangi lahan kritis serta dapat menyebabkan eksploitasi hasil hutan yang berlebihan yang mengancam kelestarian (Priambodo, 2012). 


\section{Faktor Penghambat dan Pendukung Pengelolaan Hutan di Kabupaten Sinjai}

1) Faktor Penghambat :

a) Kawasan hutan belum mantap dan jelas batas dan penataannya.

b) Terjadi konversi lahan hutan sebagai pemukiman, perkebunan, dan pertanian.

c) Lahan kritis, penggundulan dan perambahan hutan marak terjadi.

d) Semakin sering terjadi bencana banjir, tanah longsor, dan kekeringan.

e) Usaha kehutanan belum membuahkan hasil maksimal yang mengancam kelestarian hasil.

f) Investasi bidang kehutanan masih minim.

g) Terjadi distorsi pasar hasil hutan rakyat terutama hasil kayu.

2) Faktor Pendukung :

a) Teknik budidaya kehutanan sangat mudah.

b) Adanya bantuan Pemerintah berupa pengadaan bibit.
Analisa Strategis

Analisis strategis terhadap pengelolaan hutan rakyat di Kabupaten Sinjai dilakukan dengan menggunakan analisis SWOT dan pemberian bobotnya dilakukan dengan melakukan perbandingan berpasangan pada metode AHP. Hasil dari analisi ini di harapkan menjawab pertanyaan dari tujuan penelitian ini yaitu menidentifikasi peubah strategis unsur internal dan eksternal serta pengaruhnya terhadap perkembangan hutan rakyat yang mendukung pengelolaan sumberdaya hutan secara berkelanjutan di Kabupaten Sinjai dijelaskan melalui analisis SWOT (strength, weakness, opportunity, dan threat).

\section{Faktor internal}

Berdasarkan hasil wawancara terhadap pemilik hutan rakyat dan para pakar diperoleh evaluasi variabel-variabel Internal seperti yang disajikan pada Tabel 3. 
Lenny Marlina Zainal : Strategi Pengelolaan Hutan Rakyat di Kabupaten Sinjai

Tabel 3. Matriks IFAS (Internal Factors Analysis Summary) Pengelolaan Hutan Rakyat di Kabupaten Sinjai.

\begin{tabular}{|c|c|c|c|}
\hline Faktor Internal & Bobot & Rating & Skor \\
\hline \multicolumn{4}{|l|}{ KEKUATAN : } \\
\hline $\begin{array}{l}\text { 1. Nilai Ekonomi cukup baik (secara Financial } \\
\text { layak untuk diusahakan }\end{array}$ & 0,091 & 3 & 0,27 \\
\hline 2. Teknik budidayanya sederhana & 0,113 & 4 & 0,45 \\
\hline 3. Potensi pasar masih cukup besar & 0,108 & 4 & 0,43 \\
\hline $\begin{array}{l}\text { 4. Hasilnya dapat digunakan sendiri oleh } \\
\text { pemiliknya. }\end{array}$ & 0,110 & 4 & 0,44 \\
\hline Jumlah Kekuatan & 0.42 & & 1,60 \\
\hline \multicolumn{4}{|l|}{ KELEMAHAN : } \\
\hline $\begin{array}{l}\text { 1. Tingginya ketergantungan petani pada } \\
\text { pedagang pengumpul }\end{array}$ & 0,110 & 4 & 0,439 \\
\hline $\begin{array}{l}\text { 2. Batas kawasan dengan hutan rakyat kurang } \\
\text { jelas }\end{array}$ & 0,068 & 2 & 0,135 \\
\hline $\begin{array}{l}\text { 3. Rencana strategis pengelolaan pada tingkat } \\
\text { petani belum ada }\end{array}$ & 0,096 & 3 & 0,288 \\
\hline 4. Informasi pasar kurang(harga kayu kurang) & 0,102 & 4 & 0,408 \\
\hline $\begin{array}{l}\text { 5. Aksesibilitas dan kondisi topografi hutan } \\
\text { rakyat yang tidak mendukung }\end{array}$ & 0,102 & 4 & 0,408 \\
\hline $\begin{array}{l}\text { 6. Karakteristik hutan rakyat yang tidak } \\
\text { mendukung }\end{array}$ & 0,101 & 3 & 0,304 \\
\hline Jumlah Kelemahan & 0.58 & & 1,98 \\
\hline TOTAL & 1,00 & & 3,58 \\
\hline
\end{tabular}

Sumber : Hasil Analisis Data, 2017

Data pada Tabel 3. menunjukkan hutan rakyat diperoleh evaluasi variabelbahwa variabel yang relative menpunyai variabel internal kelemahan seperti yang skor paling tinggi dari variable internal disajikan pada Tabel 3. dimana pada tabel kekuatan yaitu teknik budidaya yang ini dapat diketahui bahwa variabel yang sederhana mempunyai skor sebesar 0,45 . relatif mempunyai skor paling tinggi adalah Variable yang mempunyai skor terendah variabel tingginya ketergantungan petani yaitu nilai ekonomi cukup baik (secara pada pedagang pengumpul dengan skor finansial layak untuk diusahakan dengan sebesar 0,439 yang kemudian disusul oleh nilai skor 0,27. Berdasarkan hasil variabel tingginya tingkat aksesibilitas dan wawancara terhadap para pakar dan pemilik kondisi topografi hutan rakyat yang tidak 
mendukung dan informasi pasar kurang Faktor Eksternal

(harga kayu kurang) dengan masing-

Adapun data faktor eksternal dalam

masing nilai skor 0.408. Variabel yang pengelolaan hutan rakyat di Kabupaten mempunyai skor terendah yaitu variabel Sinjai dapat dilihat pada Tabel 4.

batas kawasan dengan hutan rakyat kurang

jelas dengan skor 0,135 .

Tabel 4. Matrik EFAS (External Factor Analysis Summary) Pengelolaan Hutan Rakyat di Kabupaten Sinjai.

\begin{tabular}{|c|c|c|c|}
\hline Faktor Eksternal & Bobot & Rating & Skor \\
\hline \multicolumn{4}{|l|}{ PELUANG : } \\
\hline 1. Adanya bantuan bibit dari pemerintah & 0,198 & 4 & 0,79 \\
\hline $\begin{array}{l}\text { 2. Adanya perhatian pemerintah terhadap } \\
\text { pengembangan hutan rakyat }\end{array}$ & 0,171 & 4 & 0,68 \\
\hline $\begin{array}{l}\text { 3. Adanya pengembangan peraturan } \\
\text { pendukung pengelolaan hutan rakyat }\end{array}$ & 0,182 & 4 & 0,73 \\
\hline $\begin{array}{l}\text { 4. Tersedianya lokasi penanaman berupa } \\
\text { lahan kosong }\end{array}$ & 0,121 & 3 & 0,36 \\
\hline Jumlah Peluang & 0,67 & & 2,56 \\
\hline \multicolumn{4}{|l|}{ ANCAMAN : } \\
\hline 1. Semakin meningkatnya kebutuhan petani & 0,4 & 4 & 1,60 \\
\hline $\begin{array}{l}\text { 2. Meningkatnya permintaan kayu dari } \\
\text { pedagang pengumpul sehingga } \\
\text { mengurangi ketersediaan kayu karena } \\
\text { penebangan yang berlebih. }\end{array}$ & 0,05 & 3 & 0,15 \\
\hline Jumlah Ancaman & $\mathbf{0 , 3 3}$ & & 1,16 \\
\hline TOTAL & 1,00 & & 3,73 \\
\hline
\end{tabular}

Sumber : Hasil Analisis Data, 2017.

Berdasarkan hasil wawancara variabel adanya bantuan bibit dari terhadap pemilik hutan rakyat dan para pemerintah dengan nilai skor sebesar 0,79. pakar diperoleh evaluasi variabel-variabel Variabel yang mempunyai skor terendah peluang seperti yang disajikan pada Tabel 4. yaitu tersedianya lokasi penanaman berupa Berdasarkan data pada tabel ini dapat lahan kosong dengan besar skor 0,36. diketahui bahwa variabel yang relatif Berdasarkan hasil wawancara terhadap mempunyai skor paling tinggi adalah pemilik hutan rakyat dan para pakar 
diperoleh evaluasi variabel-variabel Hasil analisis menunjukkan bahwa eksternal ancaman seperti yang disajikan total skor faktor internal kekuatan adalah pada Tabel 4. Berdasarkan data pada tabel sebesar 1,60; faktor internal kelemahan ini dapat diketahui bahwa variabel yang 1,98; sedangkan untuk faktor eksternal relatif mempunyai skor paling tinggi adalah peluang 2,56; faktor eksternal ancaman variabel semakin meningkatnya kebutuhan 1,16. Berdasarkan nilai-nilai ini diperoleh petani dengan skor 0,70. Variabel yang posisi strategi pengembangan hutan rakyat mempunyai skor terendah yaitu terletak pada sel 3 dengan nilai koordinat (meningkatnya permintaan kayu dari 0,$39 ; 1,40)$, dan diagram SWOT-nya pedagang pengumpul dengan skor 0,47. disajikan pada Gambar 1.

\section{Analisis Matrik Internal Eksternal}

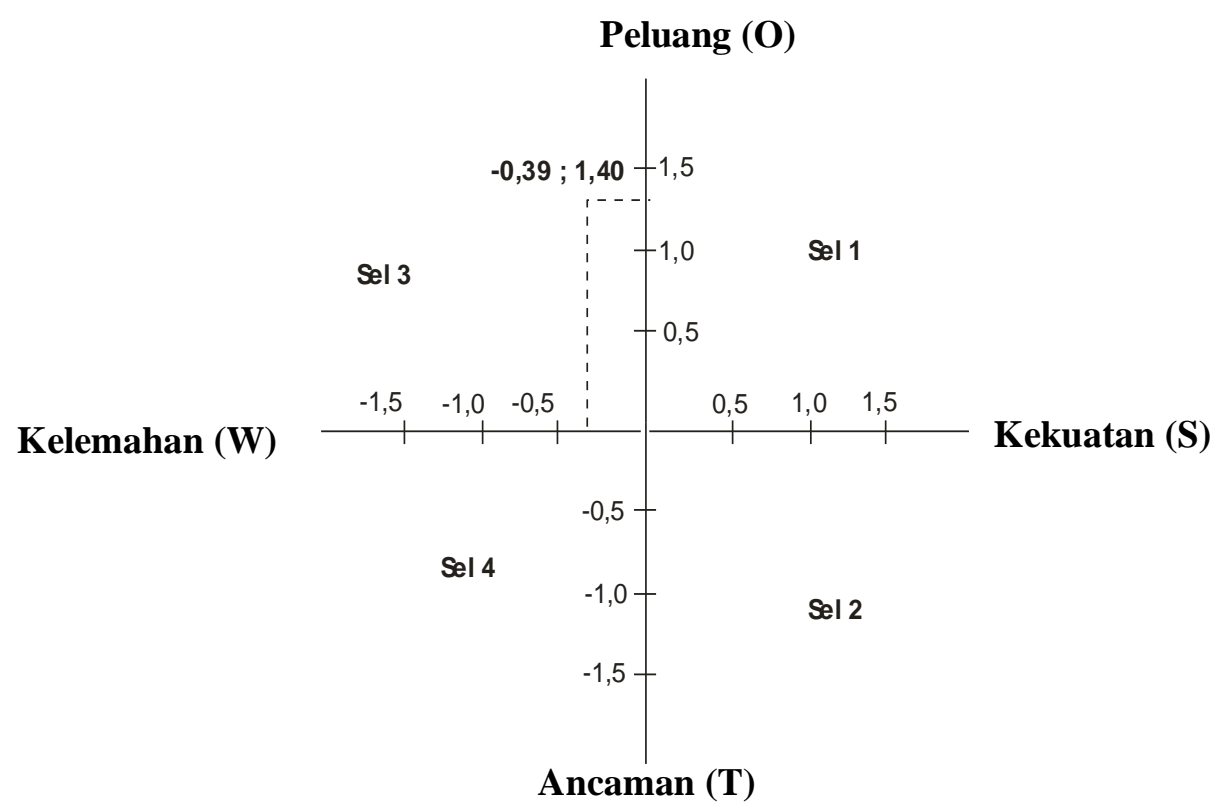

Gambar 1. Diagram SWOT Strategi pengelolaan Hutan Rakyatdi Kabupaten Sinjai.

Diagram SWOT pada Gambar 1. Kabupaten Sinjai saat ini mempunyai menunjukkan bahwa posisi hutan rakyat peluang yang sangat besar, tetapi di lain berada pada sel ketiga yang berarti bahwa pihak menghadapi beberapa sistem pengelolaan hutan rakyat di kendala/kelemahan internal. Menurut 
Rangkuti (2015), apabila posisi berada pada kuadran (sel) 3 maka sebaiknya diterapkan strategi WO (WeaknesOportunity), yaitu strategi meminimalkan masalah-masalah internal sehingga dapat merebut peluang yang lebih baik.

Posisi hutan rakyat di Kabupaten Sinjai berada pada sel 3 menunjukkan bahwa strategi yang harus di terapkan yaitu Strategi WO dengan cara :

1) Pemerintah memudahkan perijinan untuk mendirikan industri kayu untuk meningkatkan harga nilai kayu.

2) Menguatkan peran dari kelompok dengan memberikan informasi pasar secara akurat.

3) Melakukan penyuluhan kehutanan dan bimbingan dari pemerintah untuk penataan areal kawasan dan penyusunan rencana pengelolaan.
4) Mengunakan pola agroforestry

\section{Penentuan Prioritas Strategi}

Metode yang digunakan dalam menganalisis prioritas strategi pengembangan hutan rakyat adalah metode analisis hierarki proses (AHP) meliputi aspek pendanaan, aspek pemberdayaan petani, aspek kemitraan petani dan investor serta aspek pemantapan kelembagaan hutan rakyat. Menurut Gane (2007) strategi manajemen yang diterapkan pada sektor kehutanan meliputi sumberdaya, kegiatan, output, organisasi dan lembaga bersamasama sebagai suatu sistem.

$$
\text { Penentuan arahan menggunakan }
$$
indikator dari analisa SWOT yang dapat dilihat pada Tabel 5.

Tabel 5. Aspek Penentu Faktor Strategis

\begin{tabular}{|c|c|}
\hline Aspek & Indikator (Strategi WO) \\
\hline 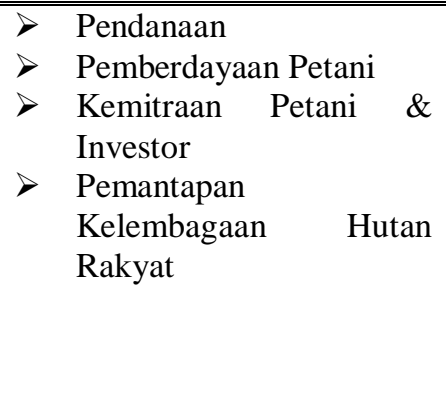 & $\begin{array}{l}\checkmark \begin{array}{l}\text { Pemerintah memudahkan perijinan untuk } \\
\text { mendirikan industri kayu untuk }\end{array} \\
\text { meningkatkan harga nilai kayu. } \\
\checkmark \quad \begin{array}{l}\text { Menguatkan peran dari kelompok dengan } \\
\text { memberikan informasi pasar secara akurat. }\end{array} \\
\checkmark \quad \text { Melakukan penyuluhan kehutanan dan } \\
\text { bimbingan dari pemerintah untuk penataan } \\
\text { areal kawasan dan penyusunan rencana } \\
\text { pengelolaan. } \\
\checkmark \quad \text { Menggunakan pola agroforestry }\end{array}$ \\
\hline
\end{tabular}


Penentuan prioritas strategi investor, aspek pemantapan kelembagaan diperoleh berdasarkan hasil analisis AHP HTR. Penentuan strategi pengembangan dimana nilai pembobotan diperoleh dari Hutan Rakyat di Kabupaten Sinjai hasil kuisioner para pihak berdasarkan berdasarkan hubungan antara aspek-aspek aspek pendanaan, aspek pemberdayaan tersebut diatas dapat dilihat pada Gambar 2. kelompok tani, aspek kemitraan petani dan

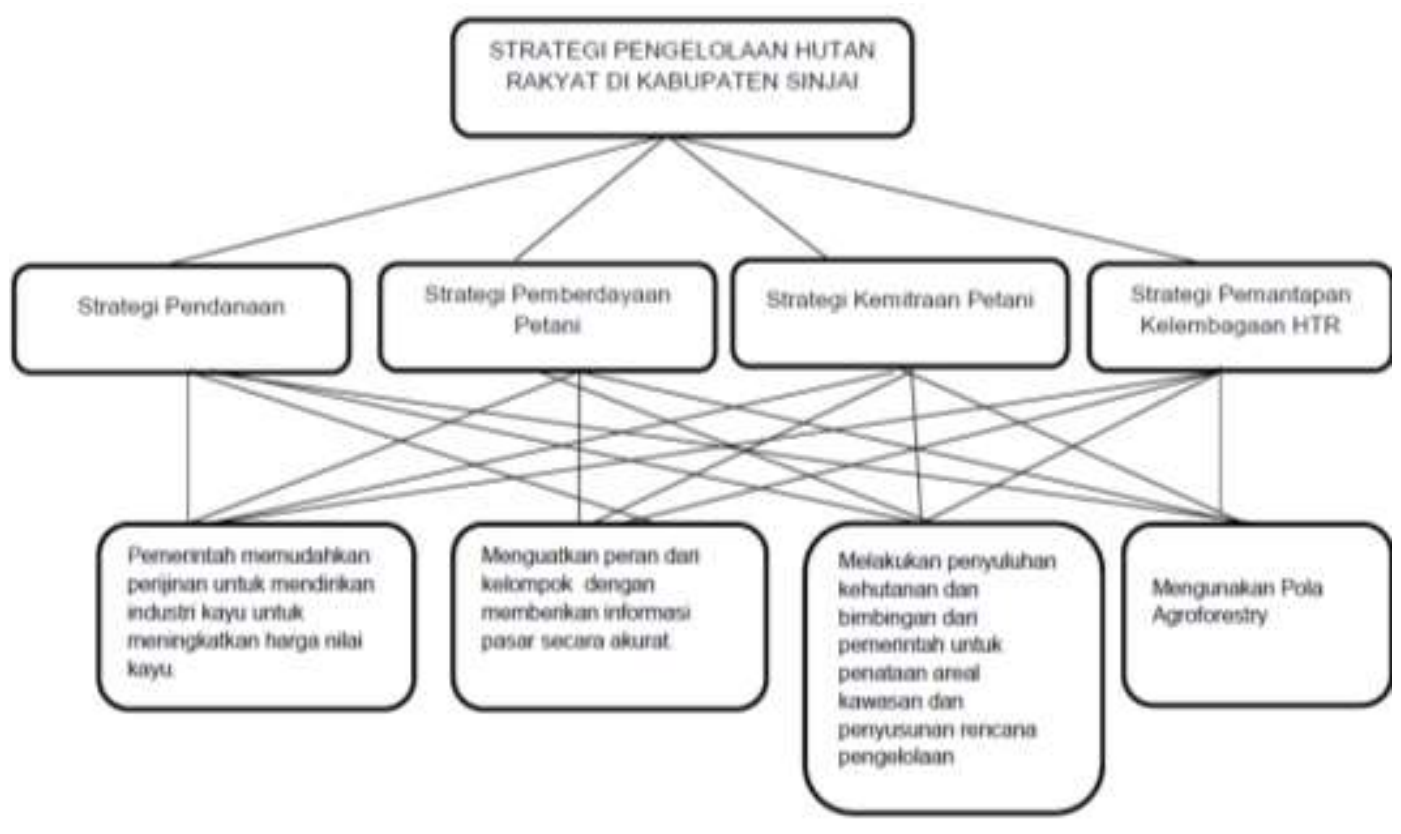

Gambar 2. Hierarki Kombinasi SWOT-AHP Strategi Pengelolaan Hutan Rakyat di Kabupaten Sinjai.

Penentuan prioritas strategi terhadap (AHP) dilakukan dengan menggunakan alternatif-alternatif strategi dasar yang telah bantuan program Expert Choice 11. Hasil dihasilkan dapat dilakukan melalui analisis terlihat pada Gambar 3. penyelesaian Analisis Hierarki Proses 


\section{Synthesis with respect to: \\ Goat Strategi pengelolahan Hutan Rakyat di Kabupaten Sinjai \\ Overall Inconsistency $=.05$}

(1) Pemerintah memudahkan perīinan untuk mendirkan industri kayu untuk meningkatkan harga nilai ...

(2) Mengualkan peran dari kelompok dengan memberikan informasi pasar secara akurat.

(3) Melakukan penyuluhan kehutanan dan bimbingan dari pemerintah untuk penataan areal kawasan..

(4)Mengunakan pola agroforestry

.152

482

257

109

Gambar 3. Hasil AHP Strategi Prioritas Pengelolaan Hutan Rakyatdi Kabupaten Sinjai.

Berdasarkan Gambar 3 terlihat bahwa hasil Analisis Hirarki Proses terhadap prioritas strategi, Strategi Prioritas Pengelolaan Hutan Rakyat Di Kabupaten Sinjai memiliki nilai inkonsistensi 0.05 . Menurut Mawardi (2013) pembobotan dianggap konsisten jika nilai inkonsistensi < 0,1 .

Prioritas strategi utamanya yaitu menguatkan peran dari kelompok dengan memberikan informasi pasar secara akurat (0.482). Prioritas kedua yaitu melakukan penyuluhan kehutanan dan bimbingan dari pemerintah untuk penataan areal kawasan dan penyusunan rencana pengelolaan. (0,257), prioritas ketiga Pemerintah memudahkan perijinan untuk mendirikan industri kayu untuk meningkatkan harga nilai kayu $(0,152)$. dan prioritas keempat yakni mengunakan pola agroforestry (0.109).

\section{KESIMPULAN}

1. Pemerintah sebagai pembuat Kebijakan untuk tata kelola kehutanan mempunyai peranan yang besar sebagai suatu arahan/pedoman untuk aparat maupun masyarakat dalam pengusahaan hutan rakyat yang produktif dan lestari. Tanpa tata kelola yang baik, pembangunan hutan rakyat dapat melenceng dari tujuan semula yaitu untuk mengurangi lahan kritis serta dapat menyebabkan eksploitasi hasil hutan yang berlebihan yang mengancam kelestarian.

2. Faktor Penghambat; (a) kawasan hutan belum mantap dan jelas batas dan penataannya, (b) terjadi konversi lahan hutan sebagai pemukiman, perkebunan, dan pertanian, (c) lahan kritis, penggundulan dan perambahan hutan marak terjadi, (d) semakin sering terjadi bencana banjir, tanah longsor, 
dan kekeringan, (c ) usaha kehutanan belum membuahkan hasil maksimal yang mengancam kelestarian hasil, (d) investasi bidang kehutanan masih minim, dan terjadi distorsi pasar hasil hutan rakyat terutama hasil kayu. Faktor Pendukung yang sering di paparkan responden; (a) teknik budidaya kehutanan sangat mudah dan (b) adanya bantuan Pemerintah berupa pengadaan bibit.

3. Faktor internal kekuatan yang dominan berperan dalam pengelolahan hutan rakyat berupa : teknik budidayanya sederhana, sedangkan faktor internal kelemahan utama adalah tingginya ketergantungan petani pada pedagang pengumpul. Faktor eksternal peluang yang dominan berperan dalam pengelolaan hutan rakyat berupa : adanya bantuan bibit dari pemerintah sedangkan faktor eksternal ancaman utama yaitu semakin meningkatnya kebutuhan petani.

4. Strategi pengelolaan hutan rakyat di Sinjai sebaiknya dilakukan dengan strategi WO (Weakness - Opportunity) yaitu dengan cara : (a) Pemerintah memudahkan perijinan untuk mendirikan industri kayu untuk meningkatkan harga nilai kayu, (b) menguatkan peran dari kelompok dengan memberikan informasi pasar secara akurat. (c) Melakukan penyuluhan kehutanan dan bimbingan dari pemerintah untuk penataan areal kawasan dan penyusunan rencana pengelolaan. (d) menggunakan pola agroforestry.

5. Terdapat empat prioritas strategi yang dapat diterapkan agar Pengelolaan Hutan Rakyat di Kabupaten Sinjai dapat berkembang dengan baik sesuai analisis SWOT dengan urutan tingkatan prioritas strategi yaitu (1) Menguatkan peran dari kelompok dengan memberikan informasi pasar secara akurat (0.482), (2) melakukan penyuluhan kehutanan dan bimbingan dari pemerintah untuk penataan areal kawasan dan penyusunan rencana pengelolaan. (0,257), (3) Pemerintah memudahkan perijinan untuk mendirikan industri kayu untuk meningkatkan harga nilai kayu $(0,152)$, dan (4) menggunakan pola agroforestry (0.109). 


\section{DAFTAR PUSTAKA}

Anonimous, 1986. Expert Choice; Decision support sofware, inc mc lean virginta.

Awang, S.A,dkk . 2002. Hutan Rakyat. BPFE-Yogyakarta

Buamona R., Hengki D. \& Tasirin 2015, Strategi Pengembangan Hutan Tanaman Rakyat (HTR) Di Kabupaten Halmahera Selatan Provinsi Maluku Utara,PPs Unstrat, Manado.

Gane, M. 2007. Strategic Management and Sustainable Development For the Forest Sector. Springer. Netherlands.

Hardjanto. 2001. Dampak Krisis Ekonomi dan Moneter terhadap Usaha Kehutanan Masyarakat : Kayu Jati dan Sengon di Jawa. Resiliensi Kehutanan. Bogor : Institut Pertanian Bogor.

2003. Keragaan dan Pengembangan Usaha Kayu Rakyat di Pulau Jawa. Disertasi Pascasarjana. Bogor : Intitut Pertanian Bogor.

Hardjosoediro, S. 1980. Pemilihan jenis Tanaman Reboisasi dan penghijauan hutan alam dan Hutan rakyat. Lokakarya Pemilihan Tanaman Reboisasi.Yayasan Pembinaan Fakultas Kehutanan UGM. Yokyakarta.

Mawardi A.Asja, 2013. Penggunaan Expert Choice pada Aplikasi AHP untuk Penetapan Komoditi Ternak Prioritas di Kabupaten Majene. www.mawadisyana.blogspot.co.id.

Rangkuti F., 2015. Analisis SWOT; Teknik Membedah Kasus Bisnis. PT. Gramedia Jakarta.

Raja E, Antara M dan Anam H., 2015. Strategi Pengembangan Usaha Hutan Tanaman Rakyat (HTR) di Desa Bumi Beringing Kecamatan Luwuk
Kabupaten Banggai. Jurnal penelitian Program studi Magister Perencanaan wilayah pedesaan Pascasarjana universitas Taddulako. Toddulako

Rosniaty., 2016. Strategi Pengembangan

Tanaman Cengkeh di Kabupaten Selayar. Tesis Program Studi Magister Agroekoteknologi Pascasarjana Universitas Muslim Indonesia. Makassar.

Rusli Buamona, Hengki D. Walangitan dan Johny S. Tasirin, 2015. Strategi Pengembangan Hutan Tanaman Rakyat (Htr) Di Kabupaten Halmahera Selatan Provinsi Maluku Utara Dengan Metode Kombinasi Swot-Ahp. Dosen Jurusan Pertanian Mahasiswa PPs Universitas Sam Ratulangi. Manado.

Saaty T.L.1993. Proses Hirarki Analitik untuk pengambilan keputusan dalam situasi yang kompleks. Setiono L,penerjemah, Peniwati K, editor. Jakarta : PT.Gramedia. Terjemahan dari : decision Making for Leaders The Analytical hierarchy process for Decission in Complex World.

Patabang M., 2007. Strategi pengembangan Hutan Pinus Rakyat di Kabupaten Tana Toraja. Tesis Pascasarjana Institut Pertanian Bogor. Bogor

Priambodo D.K., 2012. Peranan Good Forest Governance Dalam Pengelolaan Hutan Rakyat Lestari Di Jawa Barat. Prosiding Seminar HasilHasil Penelitian. Balai Penelitian Kehutanan Ciamis. 